\title{
Kill Skippy? Red Meat versus Kangaroo Meat in the Australian Diet
}

\author{
Adrian Peace
}

One of the less evident axioms of anthropological research is that, when significant events take place, it is as important to note the identities of those who are not present as it is to record the details of those who are. Since I have spent several years observing the social changes within a small Irish village where not attending meetings was as much a political statement as being there (Peace, A World of Fine Difference), I have come to regard this as a methodological imperative rather than an option. In a similar vein, I propose in what follows that if anthropologists aim to critically explore the politics behind specific 'food events' (Douglas), it is as necessary to specify which foodstuffs do not appear on the dinner table as those that do. I emphasize the influence of politics since a good deal of anthropological research into food habits details the limited relevance of nutritional considerations by contrast with the inescapable force of political ones. As is often remarked in this field of study, food is never 'just food' (Caplan 3).

Specifically, I am concerned to explain in cultural terms why kangaroo meat remains such a modest, indeed minor, presence on the Australian culinary landscape. ${ }^{1}$ It is to be found in the upper echelons of the consumption hierarchy - gourmet restaurants - and at the lowest ones - camp fires in Aboriginal fringe camps - but nowhere much in between. This is all the more striking when few Australians can remain unaware of kangaroo meat's many nutritional attributes. It is true that, as the Kangaroo Industry Association of Australia (KIAA) occasionally trumpets, the kangaroo meat industry is worth \$250 million annually. But this represents a mere 0.5 percent of what Australian households spend on red meat each year and the figure has not changed much for some time (Ampt and Owen). Then again, more than two-thirds of the industry's output is consumed outside Australia. The most important purchaser is Russia where kangaroo meat is used as beef substitute filler in cheap sausage products, a level of dependence that caused havoc in the industry in 2009 when Russia banned all kangaroo meat imports due to the threat of e-coli contamination. ${ }^{2}$

\footnotetext{
1 Killing kangaroos has attracted relatively little attention from anthropologists, except in the context of Aboriginal society which is not relevant here. The article by Morton is somewhat dated whilst that by Lien looks at it from an international vantage point. For a brief account of the kangaroo as a 'symbol of Australia', see Hatton and Thompson.

2 For details, see Delahunty, and ABC Rural, 'Russian decision puts roo shooters out of work', 14 July 2009. <www.abc.net.au/rural/news/content/2009/S2625213.htm> Accessed 5 March 2010.
} 
Kangaroo meat was a significant subject of national debate in late 2008 when the senior government advisor and prominent economist, Professor Ross Garnaut, presented the final report of his climate change review (Garnaut) to the Federal Government. Given that the Garnaut Report had been commissioned by the Labor governments of Australia's states and territories and was later adopted by a newly elected federal Labor government, this was always going to be a closely scrutinized document. The recommendation that captured media headlines was that the country aim for a 25 per cent reduction in carbon emissions by 2020, by any standards a highly ambitious target. But what became a focus of interest across the rural sector was Garnaut's proposal to greatly expand the market in kangaroo meat. In the future, he argued, Australian farmers would have to realize their incomes through a combination of conventional commodities, tree plantations, bio-fuels and the storage of carbon in soil and trees. In the mix, he proposed a wholesale shift away from cattle and sheep production to farming kangaroos in drier parts of the country where conventional agricultural practices were increasingly vulnerable to climate change.

What particularly attracted attention was Garnaut's claim that economic modelling showed that by 2020 rangeland sheep and cattle numbers could be cut by 36 million and 7 million respectively, the kangaroo population could jump from 34 million to 240 million, and the increased availability of meat from the latter could more than offset the shortfall created elsewhere. The environmental gains would be wide-ranging because kangaroos emit minimal amounts of methane from enteric fermentation whilst cattle are especially prolific. Also important would be the replacement of hard hooves by soft paws in already variously degraded landscapes.

As Garnaut hit the airwaves to detail and defend his report, the prospect of such a marked transformation in the source of meat for internal consumption and overseas export became one of the most hotly debated political issues of late 2008 . At times, discussion of this specific recommendation clearly sidelined debate over the general proposals about bio-sequestration under which it needed to be subsumed; but at all events, the prospect of kangaroo meat appearing regularly on Australia's dinner table became part of the national political discourse.

Within just a few weeks, however, the issue disappeared from view almost as quickly as it had surfaced, and having made no impact of real note on either the availability of kangaroo meat or its consumption. So the question addressed in this paper is: how did this come about and what are the lessons to be drawn about the obstacles facing those who aim to transform Australian food habits? What I propose is that, for a brief period of time and in a concentrated way with the Garnaut Report as catalyst, a host of social and cultural considerations surrounding the production and consumption of kangaroo meat came to the fore, and the fact that these were preponderantly negative in character meant 
the outbreak of competing discourses was destined to be short-lived. I make no claim to this being a comprehensive account and my approach is exclusively anthropological. My aim is capture a revealing moment when social and cultural considerations ensured that the overall trajectory of debate over kangaroo meat consumption was negative, and these included factors ranging from the sheer practicality of kangaroo harvesting to the ever emotive issue of Australian nationalism.

\section{'A few roos loose in Garnaut's top paddock?'}

To the forefront of the reaction to Garnaut's proposal was the KIAA, the national organization representing all producers involved in the kangaroo meat industry as well as the source of its significant marketing initiatives. The KIAA has played a leading role in ensuring that most kangaroo meat is currently consumed by humans rather than by pets. It was hardly surprising then that the KIAA was immediately on the front foot in support of Garnaut's recommendations: he was after all proposing an enormous expansion of consumption inside Australia in a short period of time and was doing so on lines consistent with the KIAA's current marketing strategy. Garnaut wrote: 'For most of Australia's historyabout 60,000 years - kangaroo was the main source of meat. It could again become important' ${ }^{3}$ KIAA's Executive Officer was quick off the mark in support: 'I'm fond of claiming that kangaroo has been the red meat of choice among Australia's consumers for some 40,000 years. It's only in the last 100 years or so that there's been a bit of a hiccup in its marketing program' ${ }^{4} \mathrm{Mr}$. Kelly went on to say that kangaroo meat is probably the most appropriate food of our times ... (because) ... roos don't emit methane when they burp (whilst) sheep and cattle do by the tonne and methane is 21 times worse than carbon dioxide as a greenhouse warming gas'.

It was, however, the nutritional properties of kangaroo meat that the KIAA chiefly proclaimed very much in line with its customary marketing practices. The KIAA had long pinned its marketing flag firmly to the mast of nutrition and, as it now climbed on the Garnaut bandwagon, it continued in the same vein. Mr. Kelly said: 'Kangaroo meat is extremely low in fat and half of this fat is polyunsaturated. But better still it's also very high in a compound called linoleic acid which, among other things, actively reduces blood pressure'. I will return to this consistent corporate emphasis on nutrition. For the moment, it is appropriate to note that, although the KIAA was undoubtedly the commercial

3 ABC News, ‘Roo industry backs Garnaut climate change report’, 2 October 2008. <www.abc.net.au/news/ stories/2008/10/02/2379796.htm>. Accessed 22 January 2010.

4 The West, 'Roo cullers see gold in Garnaut report', 3 October 2008. <www.thewest.com.au/default/aspx? MeunuID $=2 \&$ ContentID $=100810>$. Accessed 3 October 2008. 
body with most to gain from Garnaut's proposal, even its Executive Officer expressly doubted the industry's ability to meet the prominent economist's targets. No wholesale substitution of kangaroo meat for beef and lamb could occur in the meat marketplace until there was 'some sort of campaign convincing the world that kangaroo is the one red meat you can eat with a carbon-free conscience'.

It was not too long, however, before distinctly hostile responses to Garnaut's proposal came to the fore, the first being that of the columnist Miranda Devine, who already had a formidable reputation for her relentlessly right wing opposition to even quite modest claims from the anthropogenic global warming movement. In her column in the Sydney Morning Herald and appearances in the electronic media, she had extensively attacked international and Australian scientists for exaggerating the threat of climate change, so there was a predictability to her reaction to Garnaut and she did not disappoint her followers. 'Act hastily, roo the scare tactics' began like this:

I don't want to eat kangaroo. It's dark, chewy, gamey and smelly. But, says Ross Garnaut, the Government's guru on climate change, kangaroo is what we will all have to eat in a few years. Beef and lamb will be reserved for only the very wealthy in the brave new future he envisages, in which Australia leads the world on tackling climate change. (Devine)

Not only then was kangaroo meat unpalatable, this was an elitist proposal that would foist it on the masses whilst the professional classes would continue as normal, an abominable prospect in egalitarian Australia. Devine went on to emphasize how minor Australia's contribution to global warming was by contrast with countries like the USA and China, yet the Labor government persisted with the idea of playing a leading global role in response to climate change. Her conclusion was unqualified: 'So even if you believe everything coming out of the Intergovernmental Panel on Climate Change, and even if all Australians and their farm animals committed hara-kiri, the long-term impact on global warming of the mass martyrdom would be negligible'. Other prominent and populist climate change sceptics such as Andrew Bolt in Melbourne's Herald Sun seized on much the same point.

The next contribution was much more substantial, for it comprised the collective, enduring voice of Australia's farming population whose support for Garnaut's vision was clearly imperative. The charge - which was certainly how it appeared at the time - was led by the national president of the Australian Workers Union, Bill Ludwig. An influential power broker within Labor party ranks, he scorned the proposal that Australians consume more kangaroo meat 
because of purported environmental gains ('Climate change adviser'). Whilst he emphasized to his union members that he was 'not a climate change sceptic', his immediate reaction to Garnaut was 'hello, here's another wacko'.

The response from regional and local rural groups was somewhat more restrained, but it was noteworthy that any weakness perceived in Garnaut's argument was connected with his ivory tower status, his remoteness from the grassroots where any kind of significant structural change would have to begin. For a start, the very idea of enclosing kangaroos on any scale was so impractical as to constitute a flight of fancy on the professor's part. The amount of fencing required to corral even a small population would involve inordinate capital outlay because, not only would it have to be of exceptional length, it would need to be higher and stronger than what was required for cattle. ${ }^{5}$ Then again, even if they were somehow contained, mustering kangaroos would be either uneconomic or downright unfeasible depending on local conditions. One farmer summarized the difficulties like this: 'Let me know when you are about to yard your first mob for the weekly auction for it will be a sight not to be missed. You might make more money if you sell seats and have a grandstand to see the fun as you mark, brand and tag them for trucking to the works' ${ }^{6}$

The next set of objections related to the extensive natural resources required for kangaroo harvesting and the likely quality of the product. Environmentalists critical of the beef industry had long bemoaned the enormous quantities of water that went into producing a kilo of prime steak, but at least some kind of informed estimate was possible. By contrast, even though some authorities estimated that kangaroos consume only 13 per cent as much water as sheep (Zukerman), the corralling of large numbers would require inestimable qualities of water to maintain them, and this was to take place in rangeland areas already impacted by drought. This criticism was linked to others: kangaroos do not grow anywhere as quickly as sheep and cattle, when killed only a small proportion of their body weight is suitable for consumption (Hardman; Hacker et al.; BenAmi et al.), and, in the net-broadcast words of a livestock and crop farmer: 'Kangaroos are not a herd animal like cattle and sheep, and their natural instinct is to roam freely. They are highly sensitive to any obtrusive behaviour. Herding kangaroos in any circumstances causes immense stress resulting in death from myopathy or injury' ${ }^{7}$

5 <http://www.agmates.com/herald/eat-skippy-to-save-the-planet-what-a-cruel-joke/> Accessed 3 October 2008.

6 <http://nqr.farmonline.com.au/news/nationalrural/agribusiness-and-general/general/but-well-skipgarnauts-kangaroo-suggestion-farmers-say/1321947.aspx> Accessed 22 January 2010.

7 <http://nqr.farmonline.com.au/news/nationalrural/agribusiness-and-general/general/but-well-skipgarnauts-kangaroo-suggestion-farmers-say/1321947.aspx > Accessed 22 January 2010. Comment no longer online. 
Lastly, in this fast-accumulating litany of problems, it was repeatedly claimed that Garnaut was indifferent to the social and cultural consequences of his proposal. Farmers through to butchers, it was pointed out, share ways of life wholly determined by sheep and cattle production: to have these patterns of existence transformed within a mere two decades beggared belief, but not because farmers and their co-producers are attached to them by social inertia. On the contrary, recent decades have seen unprecedented changes in patterns of farm production and community organization. The introduction of further imposts on agricultural output in order to drive farmers away from beef and cattle to kangaroos could have no other consequence than further decimating the rural population.

In sum, the overwhelming response from the bush, the population on which the adoption of Garnaut's proposal would most impact, was negative. It failed to gain traction amongst the farmers who would have to be fully on board even to test its longer-term prospects. 'A few roos loose in Garnaut's top paddock?'s was one of the more restrained headlines, whilst a fairly representative comment posted on the same Farm Online website read like this:

Garnaut's suggestion about farming kangaroos demonstrates how little he understands the land in which we live and its wildlife as he carries about his 'bubble world' modelling. All he has got to go on with this suggestion are some unevaluated, incomplete and unscientific trials by a few farmers in Broken Hill and Central Queensland ... If this is the best analysis Garnaut can come up with in relation to kangaroos, what does it say about the veracity of the rest of his modelling? Take away the fetish for numbers and it's stuffed. ${ }^{9}$

Another email to Farm Online read: 'Only an urban-based academic would have such an impractical idea and only warm and fuzzy urban-based politicians would think it a good deal!!!', and this was quickly endorsed by another farmer: 'And this clown calls himself a Professor, after these comments he might as well because no one else will. It's time we had someone with a few brains look at the situation. Get Real!!'10

What was finally most striking was the frequency with which Garnaut's proposals were condemned as 'un-Australian' in the sense of being antithetical to national well-being because their implementation might undermine the cultural integrity - 'our unique way of life' - of the Australian bush. Garnaut himself,

\footnotetext{
$8<$ http://theland.farmonline.com.au/news/nationalrural/agribusiness-and-general/general/a-few-roosloose-in-garnauts-top-paddock/1323407.aspx> Accessed 23 September 2011.

9 <http://theland.farmonline.com.au/news/nationalrural/agribusiness-and-general/general/a-few-roosloose-in-garnauts-top-paddock/1323407.aspx> Accessed 22 January 2011. Comment no longer online. 10 <http://theland.farmonline.com.au/news/nationalrural/agribusiness-and-general/general/a-few-roosloose-in-garnauts-top-paddock/1323407.aspx> Accessed 23 September 2011.
} 
of course, argued strongly that his proposals for environmental reform were crucial to the country's future economic prosperity and stability in the face of anthropogenic climate change. But the collective voice from rural Australia was the reverse: as one farmer put it 'the professor needs to be educated about the Australian bush and to get out of fantasy land and into the real world where beef and sheep producers actually work hard for a better Australia'. ${ }^{11}$ On talk-back radio, the voice from 'the real world' was even more vehement for here was an 'egg-head academic' in the pay of the 'socialistic Labor party' who had neither attachment to nor respect for the rural heartland and the culture 'which has made Australia what it is today'. As we shall see, nationalist ideology surfaced in other forms to this. What is important to bear in mind at this stage is that it proved a consistent undercurrent as the debate gained momentum.

\section{'Just another fucking pest'}

So Garnaut's proposals provoked a range of commentary about the prospect of kangaroo as an alternative source of meat in the Australian diet, but it was the preponderantly negative response that determined the short-lived nature of significant discussion. At this stage, however, two considerations are especially relevant.

One is that the proposals were taken up and subjected to scrutiny in different quarters of Australia's animal rights movement. But these responses rarely received much attention from the mass media outlets that the farm lobby captured to marked advantage. One of the reasons for this was their calculated and dry scientific approach to the Garnaut Report, qualities that are undoubtedly meritorious but rarely generate much media interest. A good example of this was the contribution of THINKK, 'the think tank for kangaroos' at the University of Technology Sydney, which is supported by the prominent animal protection organization Voiceless and the Institute for Sustainable Futures. THINKK produced a thorough assessment of the arguments, including Garnaut's (BenAmi et al. 2), in favour of kangaroo meat replacing sheep products. But whilst the think tank cogently covered the scientific evidence, the very nature of its scientific discourse ensured that it remained marginal to the wider public debate.

The other consideration is that it would be inappropriate to detail the relatively brief response to Garnaut without also describing the predominantly negative views that were already circulating in admittedly occasional but nevertheless on-going discussion over kangaroo meat consumption. All political exchanges

11 See footnote 10 . 
need to be analyzed in terms of time and place: but their impact and endurance turn on the broader discursive flows of which they are initially a product and in which they become further enmeshed. This was assuredly the case with the Garnaut proposals: both 'roos' and 'meat' taken separately, so to speak, were the subjects of on-going political dialogue well before the economist's ideas and his 'fetish for numbers' burst on the national scene.

The immediate difficulty was that, by the beginning of the twenty-first century, kangaroos were widely and definitively labelled as 'pests'. By 2008 they were near-irrevocably saddled with this stigmatized identity, and this could hardly do other than undermine their being considered a significant source of food for the straightforward reason that Australians, like most other populations (Farb and Armelagos ; Leach), have no appetite for such creatures. Pests are to be eaten only at times of outright necessity, and even then their consumption provokes a sense of disgust. To be sure, by this juncture a number of wild animals had been singled out and depicted as threatening and invasive by departments of the environment, national research organizations and rural corporate enterprises. Kangaroos were lumped into the same stigmatized category as foxes, wild cats, cane toads and camels: together, as evidenced by the proliferation of such characterizations as 'plague', 'pestilence' and 'epidemic', they presented a serious threat to national economy and society. Kangaroos were especially prominent in media imagery since photographs of 'roo hordes' in 'plague proportions' destroying everything in their path were readily available.

What distinguished kangaroos from other pests, however, was their native status, and it was this that compounded their unattractive nature as food. In official discourse, it was obligatory to explain that they were now pests by virtue of rapid population growth, declining health and, most telling, their susceptibility to disease. Since customary rangelands could no longer support their increasing numbers, kangaroos were taking on an 'unnatural' condition, and were therefore becoming increasingly disposable. This was by no means a line of argument advanced solely by government agencies and the rest. In 2005 when I was engaged in ethnographic research in peripheral parts of South Australia, it was a regular refrain amongst local farmers. One explained to me how intensely he disliked shooting the animals encroaching on his cereal crops, but his entire livelihood was at stake: 'I don't like it at all, y'know, it's Skippy, the national symbol and all that. But the plain fact is nowadays Skippy's just another fucking pest, and we've all got to deal with it'.

Anthropologists (Fiddes) and others (Lupton; Franklin) have long pointed out the ambivalent status of meat: on the one hand a source of health, strength and power, on the other a source of sickness, revulsion and disgust. Here the important point is that the management of domestic animals is nowadays so extensive as to weight the balance in favour of the former qualities - which is 
precisely why exceptional developments that indicate the contrary prove so decisive. Overseas, the outbreak of mad cow disease is all the more devastating because cattle are considered so healthy, clean and risk-free. In Australia, the irrevocably wild and increasingly diseased status of kangaroos inexorably works against their being considered likely alternatives to beef and lamb where mainstream consumers are concerned.

Paradoxically, where this receives most confirmation is within the kangaroo meat industry, especially the KIAA which, by 2007-2008, was very much concerned about these persistent public perceptions. It mounted a series of public relations exercises to allay fears about kangaroo meat as a risk-replete commodity. 'Kangaroo harvesters' were mobilised to take journalists and photographers out into the bush to show how selective they were in targeting healthy animals, how humane they were in dispatching animals with a minimum of suffering. Rural abattoirs for kangaroo meat processing opened their doors to demonstrate their standards of hygiene were every bit as stringent as conventional meat processing works. In an article in 2008, it was reported:

To be licensed as a kangaroo harvester, Gebhardt not only needed to be a cool and consistently accurate shot but also undergo TAFE-approved training regulatory controls and compliance and strict hygiene requirements, before being assessed by two government departments.

So the roo shooter dons white plastic boots, he cuts meat up with clean knives, tags them, and puts them into stainless steel mobile freezers. (Tippet)

Perhaps not surprisingly, such attempts to present the killing and processing of wild creatures as if it were as clean and sanitized a process as deriving meat from domestic animals occasionally went awry. At the end of the day, it had to be acknowledged that kangaroos in the wild had to be killed by a bullet, joeys dispatched with a blow to the head, and carcasses butchered out in the open, in other words to illuminate precisely the violent and unsavoury features of meat supply that the mainstream meat industry has thoroughly eliminated from public view (Vialles; Franklin). In an extended article 'An industry that's under the gun' in the Sydney Morning Herald (26 September 2007), the 'kangaroo harvester' had worked hard to convince the journalist and his photographer that he was engaged in a clean and humane operation until the ultimate question was posed:

Does he knock the joey on the head or shoot it?

'You just have to give it a hard blow to the back of the head, which is as quick as being shot. Shooting it would be ridiculous; you'd wound the joey because they're so little. 
As if to underscore the point, when Maunder aims for his next kill, he accidentally hits a doe instead of the buck he wanted, although it's a clean kill.

He disposes the female's joey quickly before the journalist and the photographer see the deed. (Dow)

Despite such setbacks, the relevant point remains that in order to counter the negative influence of kangaroo meat not only being derived from wild animals but just possibly diseased at source, those involved in the industry make every effort to convince the Australian consumer that their product is as risk-free and culturally palatable as those from the mainstream meat industry. When Garnaut put forward his proposals in 2008, all such efforts were relatively commonplace. But whether they managed to impact much on the public at large remained a moot point. At all events, as mentioned previously, sales of kangaroo meat inside Australia remained relatively static.

The relevance of the mainstream meat industry was, however, more contextually consequential than this, for Garnaut's proposal coincided with one of the most expensive marketing programs mounted by Meat and Livestock Australia (MLA), the paramount nation-wide corporation in this sector. The main object of the Red Meat - Feel Good campaign was to reverse a distinct slowing up of consumption which had chiefly resulted from lower prices and effective marketing in the white meat industry, and on this count it was to prove strikingly successful. When the campaign began, red meat sales for the period 2004-2005 amounted to $\$ 8$ billion annually; in 2006-2007, they reached $\$ 9$ billion.

I have provided elsewhere a critique of the ideology behind this campaign (and the part played by anthropology in it) (Peace, 'Meat in the Genes'). In this context, the most significant consideration is that, because of the MLA's extensive financial resources, the media corporation hired to mount the campaign was able to blitz the meat marketplace with advertisements on television and magazines through to free recipes in participating butchers' shops throughout the country. The most important element was a 60 second commercial featuring Sam Neill, best known perhaps for his performance in Steven Spielberg's Jurassic Park. Other prominent figures from different walks of professional life were recruited to give the campaign scientific authority and popular appeal. The name and ideas of Lord Robert Winston, whose television series had recently been shown in Australia, were deployed to give the campaign a scientific veneer. The American anthropologist Lionel Tiger was flown in from the USA to explain why Australians revel in ritually assembling to savour a roast meal.

The campaign aimed at persuading Australian consumers that eating red meat was the most natural thing in the world to do; they should surrender to the 
call of their instincts. In image and in text, the theme was that once the apes had descended from the trees and our ancestors developed the ability to hunt, Homo sapiens emerged as the dominant species. Eating meat became, as one advertisement put it, 'as natural as drinking water', its natural proteins 'helped our brains grow', it became integral to the creativity which culminated in our superiority over other species.

According to this 'evolutionary logic', the average Australian was thus justified in following his or her instincts where red meat consumption was concerned. Rather than heeding the cautious directives of the 'body technocrats' (Lupton, Ch. 5), still less the carping of environmentalists, engrained evolutionary instincts should determine the choice of meat as a foundation food. As Sam Neill intoned whilst watching a 'typical' nuclear family at their evening meal: 'Lean meat three or four times a week is still an essential part of the diet of the most highly developed species on the planet. Red meat. We were meant to eat it'.

It was certainly the case that the nutritional value of red meat was specified in the campaign, and it (almost) goes without saying that red meat was throughout rendered synonymous with beef products and no other. But this was secondary to the neo-evolutionary theme that red meat had played a key part in mankind's unilinear progress over the millennia. Essentially, the Red Meat-Feel Good campaign aimed to explore the neo-Darwinian concerns which inform the zeitgeist of modern societies like Australia. Plain and uninspiring issues such as nutrition - which, it will be recalled, are most prominent in the effort to sell kangaroo meat - were distinctly secondary to the imaginative and innovative claim that by instinctually consuming red meat, the average Australian was part of the process of evolution and its culmination in high consumerist civilization.

In sum, Garnaut's proposal that the paramount place occupied by conventional meat in the national diet could be filled by kangaroo meat could hardly have been more ill-timed. By 2008, not only was the stigma of being a diseased pest more firmly attached to kangaroos than ever before, but the ways in which the industry's efforts to dispel these concerns were having limited effect. In addition, Garnaut's proposal was up against the MLA's innovative campaign that tapped into significant myths in the popular imagination. That campaign was, naturally, backed by substantial corporate finances; the KIAA was and remains a financial minnow by comparison. But the latter's persistent and undoubtedly worthy emphasis on kangaroo meat's nutritional composition-'extremely low in fat and half of this fat is polyunsaturated ... also very high in a compound called linoleic acid' — seemed most unlikely to significantly boost its sales. 


\section{Conclusion: to replace or to reduce...?}

By way of conclusion, it is appropriate to step back from the details of the exchanges provoked by the Garnaut Report and to emphasize the relative ease with which a narrow language about meals was uncritically reproduced across this emergent political field.

It is proper to acknowledge at this juncture that changes have been made to patterns of meat consumption in Australian society over the past few decades. As already mentioned, the Red Meat-Feel Good campaign was a response to a substantial consumer shift from red meat to white meat; and in itself, acknowledgement from within the industry that the quantity of meat consumed by the average Australian should be somewhat reduced, constituted a development with some merit. But at a somewhat different level, what was emphatically but discreetly normalized throughout the debate over Garnaut was the idea that, in the future as in the past, a proper Aussie meal still had to have meat as its centrepiece. Notwithstanding the substantial changes in eating habits which have taken place, especially amongst the younger generation with their pervasive grazing habits, whether the political protagonists were against Garnaut or with him, the taken-for-granted understanding was that the structure of a meal always revolves around the meat which constitutes its core. What remained strikingly intact throughout was the way in which meat was reproduced as 'a metonym of the very idea of food itself' (Lupton 28). Despite the irritation and ire that Garnaut provoked in different quarters of Australian society, there was a fundamental if implicit agreement between most that a real meal had to be structured around meat in some form or other.

The major result of this is to play directly into the hands of those economic and political organizations that profit most from prevailing food consumption habits. Regardless of their deleterious environmental impact, it ensures that their hegemony remains intact, for whether it is, say, MLA or McDonald's, what has to be ensured is that the meat-centred meal gets preserved at all costs. The paramount requirement is that it remains embedded in the culinary and cultural habitus of the average Australian household whose members presently consume their own weight in meat each year.

To be sure, these organizations have different corporate interests. In its Red Meat-Feel Good campaign, MLA was above all concerned to ensure that the meat-centred meal was consumed in domestic settings, which is why its light humour was targeted at mothers and wives. McDonald's, by contrast, increasingly promotes its restaurants as simulacra of the family home, places in which not only can the family meal be consumed without the labour required from the real thing, but even where it can be ascertained who and what the 
family is. But behind these corporate differences, what remains absolutely intact is the notion of a particular meat-focused meal structure, a culinary and cultural food event with deep historical roots.

Far from this being straightforward, all this is distinctly problematic since at the very least what is required from an environmentalist vantage point is the overall consumption of less meat, whatever its provenance. Put simply, we consume and waste far too much food, so the major goal has to be an overall and substantial reduction in our consumption habits. The main concern is not roast beef versus kangaroo steak, eggplant versus eggs, veggie burger versus the genuine article, and so on; it is rather that, as in so many other areas of mass consumption, our habitual eating patterns far transcend what is needed, and what the earth is able to provision us with. But at least in the short to mid-term, what needs to be debated in a modern society such as Australia is whether a meal as a significant food event can only be defined according to the presence of some meat or other. In the last analysis, the problem with the Garnaut Report was that its author was by no means radical enough: his uncritical concern was with finding a replacement, not a critical focus on facilitating some reduction.

I have already indicated that nationalist sentiments played a significant part in setting the farm population against Garnaut's proposals for significant agricultural reform in Australia. By way of conclusion, it seems appropriate to point to this same insidious influence at work elsewhere, if only to underline the specifically cultural obstacles which stand in the way of even the modest ambition of reducing meat consumption levels. Consider the influence of 'banal nationalism' of the type exemplified by, and embodied in, the governmentfunded advertisement that in 2010 promoted the celebration of Australia Day. This advertisement was to be found in a wide range of publications prior to 26 January, and it was headed 'Your Country Needs You TO BBQ LIKE YOU'VE NEVER BBQ'D BEFORE This Australia Day'. The coloured illustration depicted three positively Aryan-type figures, two men and one woman, each clutching a cellophane-wrapped plate of conventional red meat-chops, sausages and steak - and in the background, several family members milling around a barbeque draped with the Australian flag. In this fashion, through the consumption of red meat products at this unquestionably significant food event, Australians were exhorted by their own government to 'Get Involved in This Australia Day'. 


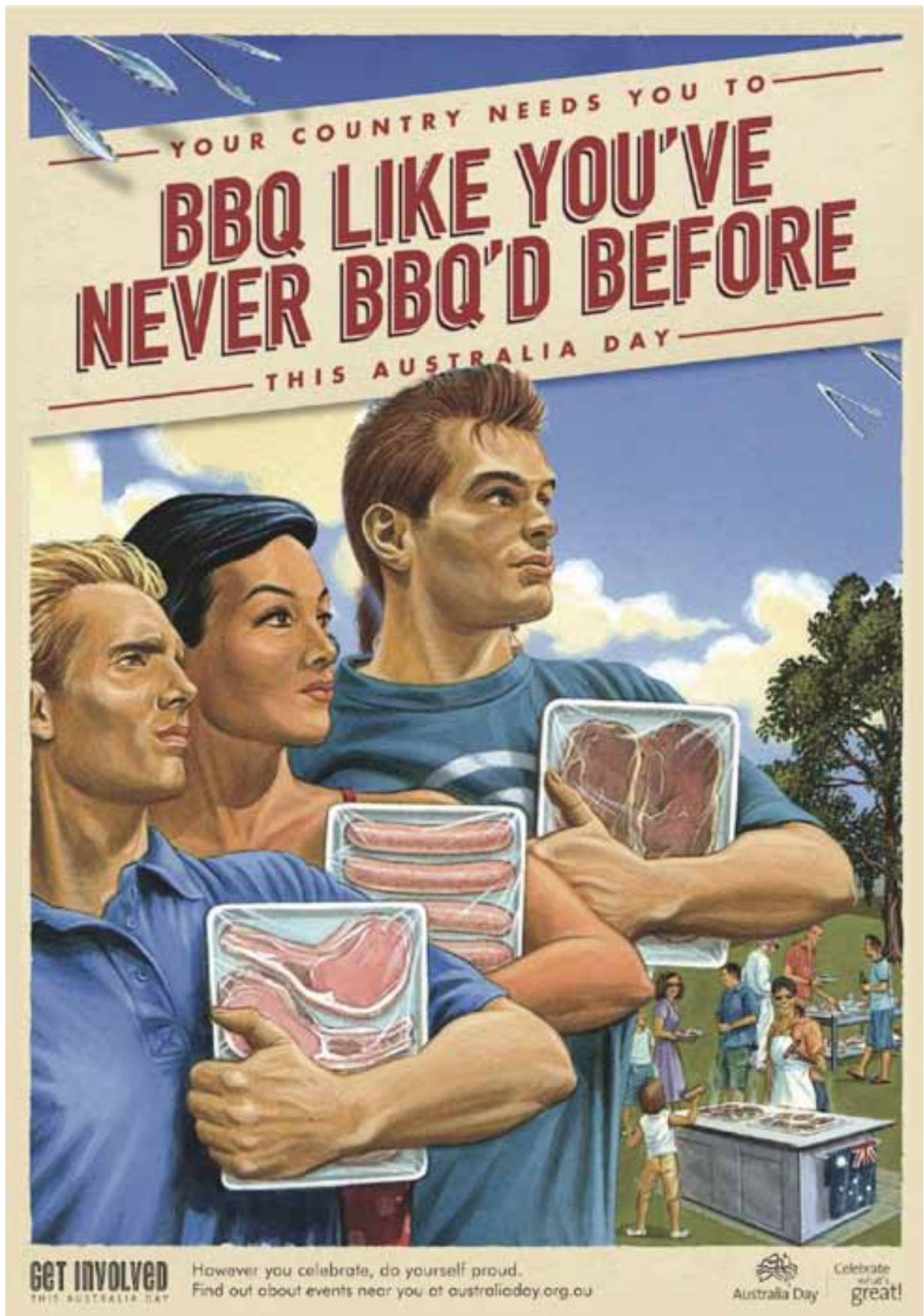

Figure 1: 'Your Country Needs You to BBO LIKE YOU'VE NEVER BBQ'D BEFORE This Australia Day.' Advertisement, 2009.

Reproduced by permission of the National Australia Day Council. 
The important point about 'banal nationalism' is the way in which entirely ordinary and unassuming items are marshalled and represented to reinforce a 'gentle and comfortable sense of belonging which is low key, taken for granted, but immensely sustaining' (Billig 6). In this advertisement (Figure 1), the consumption of red meat is strikingly associated with ideas as to what it means to be a good Australian, of what is entailed in being a proper citizen. It is the sheer ordinariness of the link humorously forged between a particular type of food and a specific understanding of national identity that is most telling. When federal and state governments throw their financial weight and much else behind promotion of such a banal notion, even the prospect of promoting a different language about meals to that which metonymically associates them with conventional red meat seems a distinctly distant one.

Adrian Peace has a D. Phil in Social Anthropology from the University of Sussex, and an honorary position in the School of Social Sciences at the University of Queensland. His most recent publications include: 'Ponies Out of Place? Wild Animals, Wilderness and Environmental Governance' Anthropological Forum 19.1 (2009): 53-72; "Man Grabs Shark With Bare Hands, Blames Vodka": On Sharks, Stereotypes, Speciesism and the late Steve Irwin' Australian Zoologist 35.1 (2009): 9-17; and 'Barossa Dreaming: Imagining Place and Constituting Cuisine in Contemporary Australia' Anthropological Forum 21.1 (2011): 23-42. He is currently writing a paper on the iconic status and commodification of crocodiles in the Top End.

\section{Works cited}

Ampt, Peter and Kate Owen. Consumer Attitudes to Kangaroo Meat Products. Rural Industries Research and Development Corporation Publication No. 08/026. Canberra: Australian Government, 2008.

Ben-Ami, Dror, David Croft, Daniel Ramp and Keely Boom. Advocating Kangaroo Meat: Towards Ecological Benefit or Plunder. Sydney: University of Technology, Sydney, 2010.

Billig, Michael. Banal Nationalism. Sage: London, 1995.

Delahunty, Claire. 'What's wrong skip?' Business Spectator, 25 November 2009. $<$ http://www.businessspectator.com.au/bs.nsf/Article/kangaroo-meatindustry-exports-russia-meat-process-pd20091124-Y458Y?OpenDocument \&emcontent_spectators $>$ Accessed 14 November 2011.

Caplan, Pat. 'Approaches to the Study of Food, Health and Identity.' Food, Health and Identity. Ed. Pat Caplan. London: Routledge, 1997. 1-33. 
'Climate Change Adviser Ross Garnaut is Branded "Wacko" by AWU President Bill Ludwig.' The Australian, 4 February 2009.

Devine, Miranda. 'Act hastily, roo the scare tactics.' Sydney Morning Herald, 2 October 2008.

Douglas, Mary. Implicit Meanings: Essays in Anthropology. London: Routledge and Kegan Paul, 1975.

Dow, Steve. 'An industry that's under the gun.' Sydney Morning Herald, 26 September 2009.

Farb, Peter and George Armelagos. Consuming Passions: The Anthropology of Eating. Boston: Houghton Mifflin, 1980.

Fiddes, Nick. Meat: A Natural Symbol. London: Routledge, 1991.

Franklin, Adrian. Animal Nation. Sydney: Allen and Unwin, 2006.

Garnaut, Ross. The Garnaut Climate Change Review: Final Report. Melbourne: Cambridge UP, 2008.

Hacker, R., S. McLeod, J. Druhan, B. Tenhunberg and U. Pradhan. Kangaroo Management Options in the Murray-Darling Basin. Canberra: Murray-Darling Basin Commission, 2004.

Hardman, J. The Wild Harvest and Marketing of Kangaroos. Brisbane: Queensland Department of Primary Industries, 1996.

Hatton, Beth and Linda Thompson. 'Kangaroo.' Symbols of Australia: Uncovering the Stories Behind the Myths. Ed. Melissa Harper and Richard White. Sydney: UNSW Press, 2010. 23-31.

Leach, Edmund. Anthropological Aspects of Language: Animal Categories and Verbal Use.' New Directions in the Study of Language. Ed. E.H. Lenneberg. Cambridge: Cambridge UP, 1964. 23-63.

Lien, Marianne Elisabeth. 'Transnational Activism and Food Taboos.' The Politics of Food. Ed. Marianne Elisabeth Lien and Brigitte Nerlich. Oxford: Berg, 2004. 179-98.

Lupton, Deborah. Food, the Body and the Self. London: Sage, 1996.

Morton, John. 'Rednecks, Roos and Racism: Kangaroo Shooting and the Australian way.' Social Analysis 7 (1990): 30-49.

Peace, Adrian. A World of Fine Difference: The Social Architecture of a Modern Irish Village. Dublin: University College Dublin Press, 2001. 
-. 'Meat in the Genes.' Anthropology Today 24.3 (2008): 5-10.

Russell, Geoff, Peter Singer and Barry Brook. Methane in an ETS. Submission to the Garnaut Review ETS Discussion Paper, 2008.

Tippet, Gary. 'The roo shooter.' The Age, 9 November 2009.

Vialles, N. Animal to Edible. Cambridge: Cambridge UP, 1994.

Wilson, G. and M. Edwards. 'Native Wildlife on Rangelands to Minimize Methane and Produce Lower Emission Meat: Kangaroos versus Livestock.' Conservation Letters 1 (2008): 119-128.

Zukerman, Wendy. 'Ecological sense in a switcheroo.' The Australian, 15 April 2009. 